\title{
The Meaning of Reputation in American Society
}

\author{
Robert N. Bellah $\dagger$
}

This Comment will present a sociological perspective on the meaning of reputation in American society. People often speak of the reputation interest ${ }^{1}$ in terms that focus on the individual. America is a culture that focuses on the individual, a culture in which "individualism" is a central value.

Yet reputation by its very nature is indelibly social. Indeed, reputation derives from the fundamental act of recognition in which the individual moves beyond interest and need and, in the words of George Herbert Mead, takes the role of the other. ${ }^{2}$ The infant who, for the first time, takes the spoon from his mother and tries to feed her is recognizing lier as a person like himself and responding to her recognition of him. Recognition inay be a psychological need, but it is not only that. Recognition is what makes society possible. Reputation is the extension and elaboration of that recognition which hies at the basis of our social existence. Thus, although we think of a person as "having" a reputation, reputation is not a property or possession of individuals-it is a relation between persons.

Our tendency to think of reputation in individualistic terms is rooted in our cultural emphasis on the autonony, independence, and achievements of individuals. In Chapter 3 of Habits of the Heart ${ }^{3}$ we describe in some detail our understanding of the life course in American iniddle-class culture, remeinbering that American culture is quintessentially niiddle-class. In this perspective life appears a search for ever greater autonomy and fulfillment of the self. In the course of this search it is necessary to leave home, often to leave the community in which one grew up and the church in which one was raised, to go away to college and then to take a job, often a series of jobs, that offers the greatest opportunity for advancement. The successful person is one who has achieved the most on his or her own. This emphasis on personal success

$\dagger$ Ford Professor of Sociology and Comparative Studies, University of California, Berkeley. A.B. 1950, Ph.D. 1955, Harvard University.

1. See Gertz v. Robert Welch, Inc., 418 U.S. 323, 350 (1974); Miami Herald Publishing Co. v. Tornillo, 418 U.S. 241, 261-62 (1974) (White, J., concurring).

2. G. MEAd, Mind, SelF \& SOCIETY 141 (1934).

3. R. Bellah, R. Madsen, W. Sullivan, A. Swidler, \& S. Tipson, Habits of the HEART 55-84 (1985). 
makes us forget how much we owe to others in everything we achieve. For example, an automobile dealer whom we interviewed in a New England town hiked to emphasize how much he had achieved through his own hard work, failing to mention that he had inherited his business from his father.

It is in the context of a career that reputatior seems most like an individual possession. For in a career one's greatest asset is one's self, and what people think of one has a crucial bearing on one's success. One's skill, one's probity, one's character, are crucial resources in climbmg the escalator of advancement in American society. Anything that would cast doubt on one's reputation in these spheres would, therefore, be directly harmful to one's life chances. It is in this context that a libel suit against a person or organization that has carelessly or maliciously mjured one's reputation makes sense. The harm suffered may indeed be calculated im monetary terms, as it is in other civil suits.

Yet in a recent study of some 900 libel cases between 1974 and $1984,{ }^{4}$ Bezanson, Cranberg, and Soloski report that of the 114 libel plaintiffs they interviewed, only about twenty-five percent reported that they brought suit primarily to win money damages. ${ }^{5}$ Most of these libel plaintiffs were public persons, highly visible to their communities, more than lialf of whom had lived in their communities for more than thirty years. ${ }^{6}$ These people claimed to have suffered emotional harm or damage to their political status, rather than primarily financial loss. ${ }^{7}$ Some seventy percent of the nearly 900 total libel cases were brought against the media, but of these, plaintiffs won only ten percent and, if they were public officials, even a smaller percentage. ${ }^{8}$ As Bezanson et al. make clear, the purpose of the suit for most libel plaintiffs was to vindicate the plaintiff's reputation. The outcome, including financial reparation, was secondary. ${ }^{9}$ As they put it, few plaintiffs "sue to win"; rather they "win by suing." 10

What these facts suggest is a rather different and, partly at least, less individualistic meaning of reputation among those in public life. It is true that their career chances would be damaged by libel; yet, their chief concern is with their standing in the comnunity, as their public effectiveness is dependent on the favorable reputation they enjoy in their

4. R. Bezanson, G. Cranberg, \& J. Soloski, Libel \& the Press: Setting the Record Straight (unpublished manuseript, University of Iowa) (on file with author). This study consisted of several parts, two of which are relevant here: a survey of nearly 900 reported libel cases between 1974 and 1984, and personal interviews with 114 libel plaintiffs. Id. at 4.
5. Id. at 11 .
6. Id. at 6-7.
7. Id. at 10.
8. Id. at 5 .
9. Id. at 25 .
10. Id. at 38 . 
communities. One should not, of course, discount purely egotistical motives, among which a desire to be reelected is obviously central. Nevertheless, if they have any desire to carry out their public trust in an effective way, as many public officials obviously do, then favorable reputation is an essential resource in effective performance. Such favorable reputation is thus a public good, not merely a private possession.

We all know that reputation is something shared and reflected. Something that reflects on the reputation of a parent, child, spouse, or friend reflects to some degree on us; we are protective of those reputations. To a considerable degree the reputation of a community is reflected in the reputation of its representative figures. Indeed, it is the founders and heroes of a community that to a considerable extent give it its identity, and it is the memory of the sufferings and achievements of exemplary figures that constitutes a community as a cominunity of memory and keeps that community alive.

For example, the founders of the American republic were very conscious of theinselves as acting in the public realm before the eyes of their fellow citizens. Washington was called the American Cincinnatus, ${ }^{11}$ the citizen-soldier who gave up power at the end of the Revolutionary War, only to be recalled by his fellow citizens from his rural retirement in order to beconie our first president. For generations of Americans he summed up the very meaning of our republic. The reputations of the founders and of sonie subsequent leaders such as Lincoln are a public resource. This does not mean that they are above scrutiny, or should be. Soine of then1, particularly Jefferson and Lincohi, have suffered at the hands of revisionist historians, but the result lias been public controversy. For example, evidence of an illicit relationship between Jefferson and the slave woman Sally Heming put forward by some listorians has been meticulously challenged by others. ${ }^{12}$ The issue is not whether the American heroes were above reproach-it would be a relief if they were notbut rather that their reputations are a matter of public importance. Who they were tells us who we are.

Thinking of the reputation of public figures as a public good, in need of protection, seems to run head on into anotlier requirement of a free society - that we scrutinize the actions of our public servants and hold them accountable. To some extent there is indeed an unavoidable conflict here between two legitimate interests. But today we, and no less the

11. G. Wills, Cincinnatus: George Washington and the Enlightenment (1984); Flexner, Cincinnatus Assayed: Washington in the Revolution, in GEORGE WASHINGTON: A PROFILE 86 (J. Smith ed. 1969).

12. Arguments for the existence of a Jefferson-Heming relationship appear in F. BRoDIE, Thomas Jefferson, AN INTIMate History (1974); P. SMITH, JefFerson: A Revealing BIOGRAPHY 210 (1976). 
1nedia, often forget that scrutiny and accountability are not the only concerns of a deinocracy: good reputation is also a public interest. In this regard it is worth noting what is soinetines said about inedical malpractice: the cause of inalpractice suits is malpractice. Sinilarly, the cause of libel suits is libel. Such suits serve the purpose of reeninding the media of their obligation to respect public reputation unless they have very good reason for doing otherwise.

Still, it has been argued that libel suits, even when they fail, are so enormously expensive to the inedia-the Westinoreland and Sharon cases are usually mentioned-that they have a "chilling effect" on freedom of the press, that they endanger first amendinent freedoms. ${ }^{13}$ To the extent that this is so, there is every reason to seek for reforms in the judicial process and for nonjudicial alternatives which would provide swifter and more appropriate remedies for plaintiffs and less onerous burdens on the media.

But there is also reason to consider whether the treatinent of public figures by the inedia does not have a "cliilling effect" on the decision of individuals to enter the public sphere because they fear what the relentless scrutiny may do to thein. To the extent that such fear deters able people from public service, this is a cost that a democratic society can ill afford. The recent vice-presidential candidacy of Geraldine Ferraro is a case in point. One may wonder whether the discovery of the questionable financial dealings of her husband, John Zaccarro, did not disproportionately obscure the record of Ferraro's public service. ${ }^{14}$

It is in connection with the kind of media publicity to which public officials are exposed that we might usefully return to the theme of individualism in American culture. Americans are fascinated by successful people-a fact known not only to People magazine-and want to know the private and intinate details of their lives. Public leaders are no exception. This fascination is enhanced by television, an intimate medium that brings distant public figures into one's living room. What results is that politics can become a form of psycho-draina. Politics becomes personalized and turns into a matter of interpersonal sensitivities. In a recent mini-series on Eisenhower, ${ }^{15}$ the focus was almost exclusively on Ike's relationship with his female jeep-driver on the one hand and his relation to Churchill on the other, the latter depicted not as a conflict over principles but only as a matter of personality management-Ike maneuvering a crotchety and vain Churchill to get what he wanted.

13. See New York Times v. Sullivan, 376 U.S. 254, 300 (1963) (Goldberg, J., concurring).

14. Sperling, Reassessing Ferraro's Candidacy, The Christian Science Monitor, Jan. 15, 1985, at 16 , col. 2 .

15. Ike (ABC television broadcast, May 3, May 4, and May 6, 1979). 
It is hard to determine the extent to which the media reflect the cult of personality in American politics and to what extent they have created it. Surely they did not create it all alone, but just as surely they have contributed to it. In any case, American politics is dominated by the personalities of political leaders to an extent rare in the modern world. Our parties are based on sentiment more than principle and neither the liberalism of the Democrats nor the conservatism of the Republicans has any coherent or consistent meaning. There are conservative as well as liberal Democrats and hiberal (or used to be) as well as conservative Republicans. Our parties, then, not based on principles and, not having much sense of membership, are congeries of local, state, and national leaders-office-holders or would-be office-holders-and their followers. Parties as such are weakly organized and can enforce hardly any disciphine on those who hold office in their name. Under the open primary system anyone can run and, often on the basis of personal charisma, be nominated. Of course some previous experience and prior media-exposure are essential, but in 1976 an obscure man who had been briefly governor of Georgia made it all the way to the White House in a matter of months: "My name is Jimmy Carter and I'm running for President."16

What is interesting about this development from the point of view of our topic-the cultural meaning of reputation-is that a politics of personality is replacing a politics of reputation. Reputation involves the building up over time of a web of connections between a public figure and a commumity, through whicl the public learns about the primciples and perfornance of the public figure. The Lincoln-Douglas debates were crucial, for example, in helping Americans define Lincoln and what he stood for, even though Douglas defeated Lincoln in the race for the Senate. ${ }^{17}$ The media, in tlins case newspapers, were crucial in the building of such a reputation. They facilitated it, but they did not create it.

But in the personatized politics of recent years the "charisma" of the leader may be almost entirely a product of media exposure and, by the same token, can disappear in the same way. Few people, for exainple, knew anything about what Jimmy Carter had done as governor of Georgia, and those who did were not encouraged. Carter was created by his media exposure in the primary campaigu and, one would have to say, in considerable measure destroyed by media exposure as President. ${ }^{18}$

An even clearer case of media destruction was the collapse of the

16. Facts on File, World News Digest, July 17, 1976, at 506, col. 3 .

17. R. HARPER, LinCOLN AND tHE PRESS 13-27 (1951) (describing the extensive press coverage of the debates and Lincoln's creation of a "national reputation").

18. For a discussion of Carter's media success, see Sperling, No More Jimmy Carters, The Christian Science Monitor, Apr. 5, 1982, at 22, col. 2. For a discussion of Carter's fall, see The Washington Post, July 27, 1980, at A3, col. 1. 
Edmund Muskie campaign in 1972 when Muskie was the frontrunner in the Democratic primary. His public weeping in the face of a nearly defamatory attack in a Manchester, New Hampshire newspaper apparently convinced the public that he did not have the stamina to become president. ${ }^{19}$ Here we are not talking about libel, but we are certainly talking about the effect of media on reputation. Again television was crucial-it was seeing Muskie cry that had the impact. But we can also say in the terms I have been using that Muskie must not have had much of a reputation or it would not have been so easily destroyed. He was not widely known as a man of principle whose performance gave evidence of his convictions.

But one could well ask who in recent American politics has had reputation in that sense. Perhaps the last American political hero was John F. Kennedy-though there is now a whole generation of younger Americans who did not experience either his life or his death-and in truth one must ask whether Kennedy was not largely the creation of style (a word frequently used about him) and media style at that-as well as whether he has not appeared larger as a result of his death than he did in life. It seems that once politicians were good actors on the public stage whereas now it is the actor who is the good politician.

One can think of at least one public figure in our recent past for whom reputation in the older sense was decisive, and that is Martin Luther King, Jr. Although the media played a role in building that reputation, they did not create it. King stood steadfastly for very clear principles-racial equality, nonviolence, and peace-and his actions were consistent with his reputation. That he may have been less than spotless in his private he in no way diminishes his reputation.

Under present electoral conditions politicians often avoid committing themselves to coherent principles for fear of alienating the voters with other views. Ronald Reagan has pulled off the consummate mirrortrick of contemporary politics by appearing to stand for coherent principles while not actually doing so--opposing budget deficits while more than doubling the national debt, for example. The public does not seem to care to notice the contradiction. Nor do the media seem much troubled by the lack of principle, because they are so at home with the personalized politics of the cult of personality. How well a candidate stands up to an aggressive reporter becomes a better indicator of his capacity for office than his political principles and performance.

What I am suggesting is that the reputation of public officials and public figures is an important matter in a democratic republic and that of late the relation between the public figure, reputation, and the media is

19. The Washington Post, Apr. 30, 1980, at Al, col. 5 (discussing Muskie's career). 
far from what it ought to be, even aside from the vexed matter of libel suits.

I am enough of an Aristotelian to believe that legislation does have an effect on the virtue both of politicians and citizens, and in this case changes in electoral laws might well be contemplated-though I liave no specific proposals, being inmdful of the fact that most recent electoral reforms seem to liave had questionable results. I am enough of a de Tocquevillian to believe that legal regulation of the media is not the answer, though I am not unsympatletic to a strong libel law.

But quite aside from legal regulation, the media in a democratic republic have important public responsibilities. These include uncovering the truth and lettimg the chips fall where they may, but go well beyond that. The preoccupation of imvestigative reporters with wrongdomg in high places is only the reverse side of the politics of personality. Both concentrate on the inotives and judgments of individuals and not on policy and performance. Many have pointed out that the Watergate break-in and coverup were far from the worst things that Richard Nixon did. The Nixon-Kissinger decision to extend tlie Indochinese War had unbelievably catastrophic consequences. The results were millions of deaths and immense suffering. ${ }^{20}$ Yet that is hardly what we remember Nixon for. Watergate and the coverup were much more sensational, inuch inore personal, mucli more accessible to the average television watcher or newspaper reader ${ }^{21}$ than policy or strategy decisions about the Vietnam War-a war, by the way, that we have never come to terms with.

But if we are to liave an educated citizenry-a critically important matter in a free society-then the media must focus on more than the dramatic actions of particular individuals-even at the highest level of government. The media inust help us understand the enormous and largely invisible complexity of the nation and tile world in which we live. Of course the media not infrequently do attempt to achieve this, even though it is easier to focus on personalities. Recently, for example, the San Francisco Chronicle had a series on consequences of tax reform in California-the results of Proposition 13-which was excellent. ${ }^{22}$ The temptation to sensationalize was on the whole avoided, the account was balanced and substantial, and it was very long-the several imstallments

20. The Vietnam War: an Almanac 358 (J. Bowman ed. 1985).

21. See, e.g., N.Y. Times, May 6, 1973, at 44, col. 1; N.Y. Times, Apr. 18, 1973, at 1, col. 8.

22. The Chronicle published the following articles in a series entitled Special Report: The Legacy of Prop. 13: Is the Tax Revolt Really Working? Now the "Chickens Come Home to Roost," San Francisco Chron., Oct. 28, 1985, at 1, col. 1; Why Repairs are Needed: A Hidden Crisis in Public Works, San Francisco Chron., Oct. 29, 1985, at 1, col. 1; Major Changes in School Financing, San Francisco Chron., Oct. 30, 1985, at 1, col. 1; The Tax Rebellion Has Cooled Off. . . But Jarvis is Still Hot to Start a New Campaign, San Francisco Chron., Oct. 31, 1985, at 1, col. 1. 
together would make a small book. For those citizens who read it all it was indeed an education.

One could say television could never do as much, but this is only partly true. Certainly the six o'clock news could not give us such a story in any depth. But to take another issue, CBS had an hour and a half special on the high tech revolution in $1984^{23}$ that was exceptionally informative as well as hely and visually interesting. Stimulating comments of outstanding economists and sociologists helped to deepen the story.

The media could do a great deal to restore the older meaning of reputation if they would try to connect public officials with policy and performance more clearly. The Chronicle story on the consequences of Proposition 13 did this in part, if somewhat peripherally and tentatively, by raising the question of Governor Deukmejian's response to the deepening crisis and pointing out what he is and is not doing about it. Deukmejian seemed to have been determined to run his reelection campaign as though his opponent were Jerry Brown, alias Tom Bradley-a typical example of personality pohtics. It would be helpful if the media held him accountable for the policies and performance of his first term. That did not happen in the 1984 national election and is not likely to happen in the 1986 California election, but it is something worth aiming at.

In conclusion, I would hike to consider another word closely connected to the word "reputation" in its legal meaning, namely "character." Defamation of character is the more general notion that subsumes hibel and slander. In defending our reputation we are defending ourselves against defamation of our character. Perhaps we could even speak of a "character interest," that, like the reputation interest, would be social as well as personal. Certainly Plato thought that the nature of the polity and the character of the citizens of the polity were closely related, indeed interdependent. He beheved that the first responsibility of a good polity was to nurture the good character of its citizens, for when the citizens become corrupt, the corruption of the polity will soon follow. ${ }^{24}$ On the other hand, Aristotle pointed out that if in a certain polity a good citizen is a bad person there is something seriously wrong with that polity. ${ }^{25}$ With these reflections in mind we might even say that the "character interest" has a certain priority over the "reputation interest," for without character there is no reputation and nothing to defame.

Such a way of putting it is unfamiliar and perhaps even objectiona-

23. High Tech: Dream or Nightmare? (CBS television broadcast, Sept. 4, 1984).

24. I. Richards, The Republic of Plato 88 (1942).

25. ARISTOTLE, ARISTOTLE's Politics, Book III.18, $\S 1$, at 144, Book VI1.13, $\S$, at 285 (B. Jowett trans. 1905). 
ble, for modern liberalism has persuaded us that character is a purely private matter and of no public concern. We all know that you can't legislate morality. That maxim has its obvious truth-for example, many of the Ten Commandments could not be legally enforced. Yet it is also true that almost all legislation has moral consequences. George Will, in one of his saner moments, points out that the Reagan administration's proposal to lower the tax on cigarettes has serious moral consequences and should be opposed. ${ }^{26}$ Laws and mores are closely related. Tax law generally has moral consequences, as does criminal law, family law, and libel law. In our fear for the freedom of the imdividual we often would prefer to ignore the fact that legislative bodies and courts do indeed shape our morals. So do the mass media, advertising, and the great concentration of economic power in our society. If our society is so organized that it encourages people to think that private ambition, material aggrandizement, and looking out for number one are the most important things, then to be a good citizen in our society is to be a bad person. At the same time, the older notion of our nation as a democratic republic with some concern for the common good would be in danger.

I hope I have not strayed too far from my topic. I have not tried to address the miceties of libel law-that is for others to do-but rather the place of reputation in American society as it was and is. Considerations about reputation have led me to character and the linkage of character, citizenship, and free institutions. I cannot think of any subject more worthy of discussion in a democratic republic.

26. Will, Deficit for a King, The Washington Post, Oct. 24, 1985, at A23, col.1. 


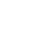

